\title{
Professionalization and Innovations in Nigerian Public Service: \\ How far the Dream of Success?
}

AFEGBUA, Salami Issa

\section{Abstract}

Uublic service accounts for a
substantial share of a country's economic activity. It is designed as an agent of fruitful change and development in the state. The transformation of any society or system depends on the effectiveness and efficiency of its civil service. The article examines the nature of professionalization and innovation in Nigerian public service. It argues that professionalization in the public service is an overarching value that determines how its activities will be carried out. The article note that various attempts have been made in Nigeria to professionalised and encourage innovation in the public service, but these have not bring about the expected changes in the public service. It therefore advocates for professionalization and innovations as panacea to the ills of public service in Nigeria. The article concludes that no public service can meet the challenges of the twenty first century without a stronger commitment to the professionalization of its workforce.

Keywords: Professionalization, Innovation, Public Service, Public Administration, New Public Management, Nigeria 


\section{Introduction}

Public administration is a key mechanism of society's attempts to sustainably improve the human condition by delivering essential services. Society therefore suffers when public administration is weak. As observed by Mishra (1998), Nigerian public administration needs to be reinvented to enhance the work capacity of the public sector. The state and its main agent, the public bureaucracy, continue to be vital to service delivery and driving national development. The effectiveness of the delivery of services by public agencies depends to a large extent on the calibre and competence of individuals manning public bureaucracy; it becomes an immediate objective and goal for every government (Mishra, 1998:2)

Public service is one of the agents of development in any nation. The transformation of any society or system depends on the effectiveness and efficiency of its Public Service, particularly the developing societies (Lawal \& Oluwatoyin, 2011). It is an institution of governance and administration established essentially to deliver public good to the people in the most efficient and effective manner. Its roles, among others, is "to carry out the burden of planning and dealing with the problems of growth and development in order to transform our natural resources into goods and services that would meet the rising expectations that come with political independence." The public service is therefore an influential public institution, which is "an instrument of public service delivery and development" (Inyang \& Akaegbu, 2014:90).

Professionalization has been a topical issue in public administration since the beginning of the $20^{\text {th }}$ century, although it has not been successfully accomplished in various instances. Discussions about professionalization began in the 1970s. This was a result of observations concerning the growing power of bureaucratic management, process-driven working methods and de-skilling of middle class labour (Meintjes, \& Niemann-Struweg, 2009:1). Pratt and Adamolekun (2008:25) argue that part of the reality of the modern world is that the best interests of professionals are constantly being undermined by innovations in procedure and revolutions in technology. While most such innovations may be harmless and even beneficial, some have a distinct capacity to undermine the security and stability of professional practice (Gold, Rodgers, \& Smith, 2002:48). The practice of public administration is no different.

The global move towards the professionalization of public service delivery has gained momentum over the past twenty-five years. This is due to democratic governments 
seeking partnership governance to achieve social-economic development with their progressive social development policies (Geoghegan \& Powell, 2006:845). To transform a public service that is characterized by corruption, low productivity, inefficiency, lack of transparency and accountability to an accountable, responsive, functioning and performance based one, there must be change of both behaviour and culture of the society (Lankeu \& Maket, 2012:265). Today governments are putting in considerable efforts in making the public service effective.

In the twenty-first century, the idea of public administration has been under constant interrogation from the principles and demands of democratic governance. The fundamental issue is couched in the question: How is the public servant to be trained and capacitated in such a way as to make the public service perform its democratic mandate? This question flows from the original conception of the public service as representing the democratic, indeed the human and humane face of the state vis-à-vis its citizens (Olaopa, 2011:2). The progress of the public service is therefore measured in terms of how well the public servants are trained to be able to carry out their tasks of providing the public goods that would make the life of the people meaningful. It is in this sense that the idea of professionalization and innovation serve as the test of genuine development for African states.

The significance of improved public service professional capacity has long been recognized in both academic and organizational settings. Yet the question of how to shape the future of a more professional public service remain highly topical, particularly an environment that is characterized by wide scale social and economic development as well as organizational change (Fatile \& Adejuwon, 2010b:81).

The main thrust of this article is that professionalization and innovation are important to address the problem of inefficiency faced by the public service in Nigeria. This article argues that professionalization and innovation in the public service can go a long way in diffusing the brewing tension in the public sphere. The research methodology applied is essentially of a qualitative nature where secondary sources in a literature survey are consulted from existing research.

\section{Conceptual Discourse}

The two major concepts in this article are professionalization and innovation. In this section, attempts were made to explain these two concepts. 


\section{Professionalization}

Professionalization is one of the most controversial issues ever discussed in the academic public administration literatures. Scholars in the field have debated all aspects of professionalization at different levels of intensity for over 100 years and the result has been a stalemate. Positive aspects of professionalization are widely acknowledged and broadly accepted, but the same is true of the narrative against it. In the present day, professionalization has become a fringe topic, lurking just out of view in the shade of other more popular matters. Professionalization brought public administration into existence and gave it purpose. It is about commitment and the embrace of an ideal: goals and outcomes can be flexible, and excellence is somewhat dependent on the context (Gornitzka \& Larsen, 2004:461).

The word 'professionalization' is derived from the word 'profession'. Profession according to Hart (2012:57) was first analysed comprehensively by Carr-Saunders and Wilson in 1933; the results are still regarded as the standard history of profession. The concept of professionalization is regarded as the process to achieve the status of profession and has been interpreted as the process to pursue, develop and maintain the closure of the occupational group in order to maintain practitioners own occupational self-interests in terms of their salary, status and power as well as the monopoly protection of the occupational jurisdiction (Larson 1977, Abbott 1988). Professionalization is 'not a simply collective action by a cohesive group, but a complex social process' (Leung, 2011:3).

Professionalization is linked to a need for raising standards of practice by means of a standardised, cohesive and effective movement (Fitzsimons, 2010:54). Professionalization is 'the means by which an occupation alters its socio-professional situation and becomes a profession by acquiring professional attributes'. Evetts (1999:120) defines it as 'the series of diverse and variable, social and historical, processes of development, of how work sometimes becomes an occupation ... and how some occupations achieve various forms of occupational control of work'. The latter definition proves that several processes of professionalization exist - and that there is no one 'blue-print' to follow during the professionalization of an occupation.

From the above, four major features of professionalization can be identified. The first is linked to specialized knowledge and expertise. That is, all members of a profession are expected to have a certain degree of theoretically and empirically based knowledge 
acquired through education or training at acknowledged institutions. In order to improve professional performance, research and development is carried out on the issues related to the profession. Assuring that all members have a "decent" education or training guarantees the intellectual level of a profession. Second, there are demands on the practices of a profession, described in code of ethics (Gornitzka \& Larsen, 2004:457; Van Bockel, 2005:5). The third is the continuing desire to raise the profession's formal status and strengthen its public image and prestige. This can be reached through creating a common professional culture and identification. Making sure that members can fully develop themselves in the field and make a living out of their profession in a full-time job sets the basis for a profession's formal status. The fourth component of professionalization has to do with professional autonomy and delegation of power to the associations (Mosher, 1982; Gornitzka \& Larsen, 2004:463).

Given that the definition of professionalization is complex, careful consideration has to be given to how we measure professionalism and what degree of it can be attributed to success in public sector reform and new public management efforts. Furthermore, there is the issue of what is being measured; what aspect of employees' performance is being predicted for improvement; and what numbers of measures are to be selected.

\section{The Concept of Innovation}

Public administration has become a fertile ground for innovation, a phenomenon that has been approached from different angles. In most literatures, innovation carries a more general meaning and is viewed mainly as a process that aims to contribute new solutions to unresolved social problems. It also focuses on the type of social relationships generated by these innovations, such as organizational innovations (management and coordination relationships) and institutional innovations (power and regulatory relationships) (Lévesque, 2006 cited in Lévesque, 2012:15). This article subscribe mostly to the first meaning given to the term, although at times make use of the second meaning when it appears expedient, in particular with regard to public services.

Defining innovation is difficult because the concept depends on the context where it is nurtured. Innovation is easily mistaken with positive effects such as increased public value and advances in public goods (Bland; Brunk; Kim \& Lee, 2010:2). As a result a number of different conceptualizations and definitions of innovation exist. So while the 
experience of innovation may be intuitively easy to comprehend by specific actors, innovation in itself has proven harder to pin down as it borders on a wide range of phenomena and concepts.

The word innovation means to introduce new thing. Without innovation capability, there would be no computers, aero-planes, high tech television, and wireless technology, just to name a few. Innovation has been practiced throughout human history and has become a way of improving human life. The concept of innovation has developed mainly around private business, with historic focus on product innovation. Innovation in services is more difficult to define and identify, particularly innovation in public services. Innovation in the public sector does not always result in new public services, but may be linked to institutional renewal, new forms of governance, process innovation, digitisation and/or organisational improvements, i.e. changes in management techniques, the introduction of performance management or strategic planning etc, in which case it is not always labelled as "innovation". To Osborne and Brown (2005:140), innovation is about the introduction and adoption of new ideas that produce a change in the existing relationships between an organization and its internal and external environments. It is a process in which valuable ideas are transformed into new forms of added value for the organisation, customers, employees and stakeholders (Merx-Chermin \& Nijhof, 2005: 137). On the other hand, Rogers (1983:11) sees innovation as 'an idea, practice, or object that is perceived as new by an individual or another unit of adoption'.

Innovation in the public service refers to conceiving a creative idea and successfully implementing it to solve a pressing public service problem. It is an effective creative and unique answer to new problems or a new answer to old problems. In terms of public perception, innovation should be a core activity of the public sector. The goal is to help public services improve performance and increase public value; respond to the expectations of citizens and adapt to the needs of users; increase service efficiency and minimize costs. The public sector has been successful at innovation in the past (Hamson, 2004:14). How to seek out and foster innovation in all public programs is crucial to continual development and improvement: only half of all innovations are initiated at the top of organizations. Maintaining diversity of staff, paying attention to the needs and expectations of users and frontline staff, and promoting formal creativity techniques are all valuable tools to ensure innovation is sought (Jessica, Christopher \& Kimberly, 2011:3). 
It is important to note that innovations in public administration and in most public services spread more through institutionalization, namely through the recognition and support of public authorities, than through market forces. Moreover, the role of the state remains significant in market or quasi-market situations, and state-regulated redistribution consolidates the demand for services deemed essential (Le Grand \& Bartlett, 1993). This is evident in Nigeria where government has been playing major role in reforming the public service towards professionalization and entrenchment of innovation.

\section{Public Service Professionalization}

Professionalization in the public service is an overarching value that determines how its activities will be carried out. It encompasses all other values that guide the public service such as loyalty, neutrality, transparency, diligence, punctuality, effectiveness, impartiality, and other values that may be specific to individual countries (Olaopa, 2011:3). Public service professionalization represents the process of attracting, selecting and creating the corps of civil servants, specialised in the area of public management, in order to apply the principles of public management, its modern techniques and methods, aimed to achieve the public institutions' mission.

Public service professionalization is underpinned by the unique set of values upheld by its members. It resides in how skilful and how well a public service employee performs his/her functions and duties and that it manifest in public servant's behaviour and the skills that are necessary for carrying out his/her task and enhancing output and productivity (Adegoroye, 2005:5). As observed by Fatile and Adejuwon (2010a:194) professionalization is a much wider task than implementing civil laws and introducing personnel management improvements. For instance, if the administrative structure within which officials are working is not also improved, they might still have to make arbitrary decisions, with insufficient communication with the public and insufficient coordination with other institutions, even in a situation where they have been selected on merit and are subject to systematic training.

There is a need for professionalization in the public service because of the new capacities to exploit new opportunities and to ensure that all civil service functions are carried out to the highest professional standards. The skills needed in the public service, both now and in the future put greater demands on public servants and call for more 
professionalism in public management (Fatile and Adejuwon, 2010b:181). In the same vein, Jane (2008:2) noted that the changing environment and the changing expectations of public servants have ensured that enhancing professionalization of public sector leaders has become a major part of public management. Professionalization is of course a question of training managers and staff, but this is not all. It is of course also a question of introducing regulations defining duties and corresponding rights of staff as in civil service law; a question of establishing administrative context in "which officials can carry out their duties in a professional, impartial, transparent and controllable way (Staffan, 2009:16).

Professionalization of the service entails that all civil servants were expected to perform specialized or professional functions (Maduabum, 2006:67). It has come to mean the pursuit of excellence and just competence. As argued by Staffan (2009:18), professionalization is not only about the quality of staff and their status. It has to do with the following:

(a) The quality of substantive law, providing the substantive framework for decision making, i.e., the tool for the officials and the source of information and prediction for the public.

(b) The quality of procedural legislation, providing procedures for administrative decision making, for co-ordination and for balancing of powers, for officials relations and communication with the public, and providing opportunities for concerned physical or legal persons to have a say or to appeal.

(c) The quality of financial and administrative accountability and control mechanisms, providing for transparency, checks of financial and administrative decision making and including means of correction, prosecution and redress (Staffan, 2009:18-19).

Public service professionalization embraces the notion that those people who join the public service need to be inculcated with shared values and trained in basic skills to professionally carry out these official duties. It requires thorough understanding of professionalism and strict adherent to public norms of model behaviour. 


\section{Public Service Innovation}

The public sector has traditionally been viewed as being radically different than the private sector in terms of innovation, with the public sector often seen as a regulatory framework for innovation in the private sector, and as a passive recipient of innovations from the private sector. However, in recent years, public sector innovation has been increasingly regarded as a central factor to sustain a high level of public services for citizens and businesses, as well as addressing social challenges and improving welfare. Public sector innovation may have considerable effect not only on the quality and efficiency of public services itself, but also may influence the private sector's ability to innovate (Bloch, 2012:3).

Innovation has the potential of opening new doors, reformulating old problems, breaking with policy deadlocks, bringing new actors together and formulating and implementing new ideas (Sørensen \& Torfing, 2012: 3). It has become the gateway to growth, economic transformation and decrease in poverty. A country's capacity to influence the creativity of its population and promote new commercially relevant ideas and products has become critical to upgrade institutions and economic activities that are essential for making use of new tools. An innovative public sector that offers quality services acts to strengthen relations between the public sector and citizens. While there is growing awareness that much innovation currently takes place in the public sector, it is also recognised that more systematic efforts to promote innovation are needed to address the economic and societal challenges that public sectors face (Koch \& Hauknes, 2005; Eggers \& Singh, 2009). As noted by Albury (2005) it is only through a process of innovation that public services can shift out of a 20th century 'mass provision' mode to a more personalised mode. Without innovations in the areas of staffing, organisation and delivery, service agencies will not be able to adapt to these changed demands.

Amongst other things, innovation is considered essential to:

$\checkmark$ reducing costs and increasing productivity, thereby improving profits and strengthening the organisation

$\checkmark$ maintaining competitiveness in a globalised economy;

$\checkmark$ the organisation's ability to adapt to changing environments (which may be legislative, technological, social, economic, and physical); 
$\checkmark$ breathing new life into slowing or stagnant markets or other operational areas; alternatively, facilitating entry into new markets;

$\checkmark$ inculcating an organisational culture of creativity: particularly visible in research oriented organisations or those working in dynamic markets like ICT, but also relevant to any organisation which seeks to attract high quality creative staff and managers at any level (Damanpour \& Gopalakrishnan 1998; Hargadon \& Sutton 2000; d'Aveni 1994).

Innovation is crucial for effective public service management in a dynamic society, characterised by 'hyperchange' - defined by Barrett (1998:288) as 'a combination of linear, exponential, discontinuous and chaotic change'. Innovation in the public sector and how innovation is perceived depends to a great extent on the nature of public services. There is also a great degree of heterogeneity in public services, where the differences among public units, both in terms of size, focus, objectives and outputs, are arguably even greater than for the business sector. For example, there are institutions providing services to individual users (which perhaps are those that most closely resemble business services), institutions providing collective services to all citizens, and administrative institutions providing services to other governmental organizations (Bloch, 2012:7). This shows that innovation is very crucial to Nigerian public service in order to provide effective services to the people.

\section{New Public Management and the Idea of Professionalization and Innovation in the Public Service}

In this section, attempt is made to look at how the New Public Management (NPM) approach has influenced professionalization and innovation in public administration.

At the beginning of the twenty first century many of the world's nation states are engaged in serious efforts to reform their government and inject a culture of innovation into their government's bureaucracies (Kamarck, 2003:2). The NPM movement began in the late 1970s and early 1980s. Its first practitioners emerged in the United Kingdom under Prime Minister Margaret Thatcher and in the municipal governments in the United States. (e.g., Sunnyvale, California) that had suffered most heavily from economic recession and tax revolts. Later, the governments of New Zealand and Australia joined the movement. Their successes put NPM administrative reforms on the agendas of most 
Organisation for Economic Cooperation and Development (OECD) countries and other nations as well (OECD, 1995). As a result, it was supported by most of the big international institutions such the World Bank, the IMF, the United Nations and the (United Nations, 2006).

NPM can be considered 'a set of new ideas about the role of government' as well as 'a set of managerial innovations in the public sector' (Van de Walle \& Hammerschmid, 2011:3). Over the last three decades, NPM has become fashionable amongst politicians, policy-makers and scholars of public sector management (Brunsson \& Kirsten, 2000). NPM has been associated with the introduction of market mechanisms in the public sector, including the introduction of concepts such as entrepreneurialism, innovation, and customer responsiveness in the delivery of public services.

The current trend in public administration is hinged, among other things, on a managerial ethos which seeks to drive public managers to achieve productivity gains driven by a responsive and professionalised workforce. The NPM-style reform that dominate reform ideas in Africa for example, is especially concerned with the issue of a shift from 'appraisal' to 'analysis', the introduction of performance management systems, the increase in the responsibility of public administrators especially as human resource managers, the introduction of market mechanisms into the public sector, the introduction of quality management techniques (Tamekou, 2008: 218 cited in Olaopa, 2011:3).

There has been a long-drawn-out, ideologically charged debate about the pros and cons of the new public management, or NPM as it is commonly known. This debate tends to focus on the allure or otherwise of NPM reforms in principle, and their timings and appropriateness. Whilst both critics and advocates of NPM accept that it can be universally understood and applied, there is never-the-less a whiff of rhetoric around it. There is some catch-phrases feature prominently in the vocabulary of civil service reform all around the world (Thomas 1996). Yet, professionalization must be central to NPM. This is because NPM as a whole deals with the content of reform, that is, the substance. However, professionalization which is a critical component of sustainable capacity building is about the entirety of the process of administration. This is why NPM measures can be implemented but not sustained without a rigorous and robust implementation of capacity building measures, thus either installing or enhancing the 
basic skills and tools of administration. This should be the initial goal of building a sound foundation.

Hood (1991:4-5) was the first to characterize NPM as an ideal type that enhance professionalization and innovation in the public service. This is based on the following elements:

(a) 'Hands-on professional management in the public sector.' This refers to giving more autonomy to those at the head of a public organization by means of a clear sharing of responsibilities and a better accountability.

(b) 'Explicit standards and measures of performance.' To this end, the targets, objectives and indicators must be better defined if one wants quantitative evaluations of the performance and a superior accountability.

(c) 'Greater emphasis on output controls.' Diverse innovations could be proposed to implement incentives for an improved performance.

(d) 'Shift to disaggregation of units in the public sectors,' which aims for a decentralization of administrations and management systems alongside relatively independent operational units with budgets leaving great leeway to managers, the whole with a view to greater effectiveness.

(e) 'Shift to a greater competition in public sector.' The aim here is to achieve cost reduction and greater effectiveness by introducing competition among units within or outside of the public sector through tendering procedures.

(f) 'Stress on private-sector styles of management practice' through the introduction of private sector management tools in the public sector, leading to, among other results, more flexibility in the hiring of personnel.

(g) 'Stress on greater discipline and parsimony in resource use.' Following the example of the private sector, public administration is encouraged to be more frugal and to reduce costs, in particular concerning human resources (cited in Lévesque, 2012:28).

It is important to note that the above elements of NPM was inspired mainly by the British experience, and they provides elements found in most public service reforms especially in developing societies. 
The value of 'effectiveness, efficiency and economy' which the NPM promotes affects the personnel management system of the public service. It motivates a 'reconfiguration of expertise and its management'. In other words, the new managerial ethos draws on a 'revised form of professionalism which has more to do with the "responsibilisation" of labour' (Dent; Chandler and Barry, 2004:2). This underscores the current effort to shift from the procedural culture of 'doing the right things' to the managerial one of 'doing it right' through the management of resources and operations. It is important that to achieve the goal of effectiveness and efficiency in the management of resources, the public servants should be given serious attention. This can be done through training. This shows that public officials in Nigeria should be adequately trained in order to meet up with the challenges of providing effective services to the people.

According to the NPM perspective, innovation is initiated and conducted by the producers. To get there, NPM makes two requests. One, 'public managers innovate', in compliance with the managerial approach, and two, aligned with public choice theory, 'Make public managers innovate', namely by exerting internal pressure (control) on the latter and external pressure by creating competition (Verhoest et al., 2007:470-471). The reforms and innovations realized with the NPM approach have produced significant changes in the restructuring of the administration (Aucoin, 2002:115).

\section{Professionalization and Innovation in Nigerian Public Service: An Overview}

Nigeria is Africa's most populous country, home to about 160 million individuals, double the size of any other African country or 20 percent of all the population of sub-Saharan Africa. It thus represents a leading setting in which to understand the determinants of public service delivery in the developing world. It also shares other important features with other developing countries: government expenditures represent 26 percent of GDP, very much in line with countries at similar stages of development; it has generally weak institutions holding government to account, and corrupt practices in public sector organizations are commonplace (Rasul \& Rogger, 2013:7).

From 1985 to date, Nigeria has had five specific reform attempts aimed at refurbishing the professional status of the Nigerian civil servant. The following are reforms experienced in Nigeria: the 1985/1988 Phillips Commission, the Ayida Reform of 1995, the Obasanjo Renewal Programme, Yar'Adua Civil Service Reform Programme and 
the present Jonathan Transformation Agenda (Olaopa, 2014:4). All these reforms had a very simple objective of reconstructing the personnel of the Nigerian civil servants through professionalising the Nigerian Civil Service and its human resource management architecture. Some of the essential steps taken in this direction include:

(a) To re-professionalise as a means of creating a new generation of officers and technocrats with sufficient skills, knowledge and motivation for institutional innovation;

(b) the conduct of vigorous and systematic evaluation and reporting of professional performance to make policy-makers accountable for resources used and for results;

(c) modernizing core operations and systems of the Nigerian Civil Service using ICT;

(d) creation of a number of more specialized cadres;

(e) putting in place a system of capacity utilization wherein core skills are better matched with jobs;

(f) injection of high skills and competencies available in other sectors of the economy into the public service, using a range of incentives; and

(g) strengthening policy and research synergies through enhanced collaborative projects, including public-private partnerships (Olaopa, 2014:5)

The current effort to reinvent core values in public administration underscores the notions of "doing the right things and doing it right." These are the marks of professionalism. Various approaches undertaken to promote professionalism in the Nigeria public service include:

$\checkmark$ Rightsizing of the service

$\checkmark$ Restructuring of ministries

$\checkmark$ Service wide capacity building

$\checkmark$ Review of performance management system

$\checkmark$ Review of public service rules and regulations, and

$\checkmark$ Promotion of ethical conduct (Adegoroye, 2005:6).

It is important to note that since 2005, no other serious reform has been carried out in Nigerian to achieve professionalization and innovation in the public service. 
The initiative of the Nigerian Government to professionalise the public service include: the review and revision of civil service rules, conclusion of Service Compacts (SERVICOM) with the Nigerian people, establishment of SERVICOM nodal units and of SERVICOM Compliance/Evaluation Index, and the setting up of the Due Process Office, the Independent Corrupt Practices Commission (ICPC), as well as the Economic and Financial Crimes Commission (EFCC) (Balogun, 2008:38).

In terms of improving performance through professionalization and innovations in Nigeria civil service, the Federal Civil Service Commission introduced innovation in Appointments, Promotion and Discipline. These new innovations, as stated by Nwanolue and Iwuoha (2012:17) which the Commission believe will bring to bear on the Civil Service Reforms focused on three major areas:

\section{Recruitment}

(a) That professional examination bodies and professional organizations should be involved in the recruitment exercises. This will bring about standardization, uniformity and transparency;

(b) That transfer and secondment into the Federal Civil Service should be limited to critical areas of needs in order not to jeopardize the promotion prospects of serving officers; and

(c) That a database inventory to determine the capacity and requirements of the Civil Service and utilization of such resources through a suitably designed pooling mechanism be established. This will help check the suppression of vacancies where they exist.

\section{Promotion}

(a) That promotion in the Civil Service should be based on the attendance and successful completion of short time training programmes by civil servants on their professions, management and leadership;

(b) That promotion in the Civil Service at certain Grade Level be tied to membership of professional organizations; 
(c) That officers on secondment to international organizations abroad should, on their return, be permitted to sit for promotion examination and if successful should be granted appropriate notional promotion to enable them be at par with their colleagues;

(d) That notional dates of conversion/upgrading of officers should be the dates of acquiring the relevant additional qualifications;

(e) That officers who pass promotion examination but could not be promoted due to vacancy constraints should not be subjected to repeat such examinations when vacancies become available. Such officers should be promoted in order of merit of their performance in the examination whenever vacancies are available; and

(f) That officers who passes the required promotion examination should have their salaries upgraded to the next level and the salary be made personal to them.

\section{Discipline}

(a) That the extension of suspension and interdiction of an officer beyond three months in the first instance must be approved by the Commission failing which the Commission reserves the right to recall such officers;

(b) That Ministries/Extra-Ministerial Departments should respond to all disciplinary cases pending before them for review within four weeks and those for retirement from Service in public interest should be concluded within two weeks;

(c) That Ministries/Extra-Ministerial Departments, in handling delegated disciplinary cases, should forward to the Commission minutes of deliberations to ensure standardization and uniformity and that all such actions are taken in accordance with the extant rules;

(d) That all cases involving criminal offences and which attract legal proceedings like theft, embezzlement and fraud be allowed to go through the normal judicial process in accordance with Public Service Rules on charges of misconduct in the matter; and 
(e) That decisions of the Commission on all appeal cases be conveyed directly to the appellants through their Ministries/Extra-Ministerial Departments (Nwanolue and Iwuoha, 2012:17).

Despite the introduction of professionalization and innovation in Nigeria, the public bureaucracy is beset with a number of problems that have hampered its effective role in governance in the country. One of the major problems confronting the public bureaucracy in Nigeria is its politicisation. Several offices in the civil service were at one or the other politicised by the military. These include the offices of the Permanent Secretary and the Head of Service. Although, there is nothing wrong with the bureaucracy performing political functions, but the fear is that unless such political functions are carefully controlled, they can further aggravate the already strained relationship between the political officers and the bureaucrats, with unpleasant consequences during a democratic regime. The political officers would regard such political roles performed by the bureaucrats as usurpation of powers and trespass (Okotoni, 2001:225).

\section{Conclusion: Exploring the Remedies}

Without an efficient and effective public service, the implementation of government policies and programmes that are aimed at improving the living condition of the citizenry will be seriously impaired. A professional public service operates on the basis of rules, regulations and procedures to ensure orderly conduct and uniform standards.

In order to achieve efficiency in the public service, there is the need for continuous training of the public servants and for a developmental oriented technocrats training and updating of their technical expertise remains cardinal. As it is a common knowledge formulation and implementation of development policies requires up to date technical and professional expertise, it therefore becomes pertinent for officers responsible for planning and development to updates themselves with relevant knowledge surrounding the demands of the position they occupy. The basis of such training and development is necessarily to improve motivation, performance and productivity of the technocrats and bureaucrats.

No public service can hope to meet the challenges of the twenty-first century without a stronger commitment to the professionalization of its workforce. Inventing a high 
performing public service, therefore, involves a constant relationship between the processes of recruiting, professionalization and 'reprofessionalization'. In this context, professionalism involves the pursuit of both excellence and competence that achieves a practical link between 'knowledge and theory and the fulfilment of public purpose (Olaopa, 2009: 57). The capacity of most public services in the world today to effectively and efficiently carry out their administrative functions is judged in global terms by the system of high performance management in place that will initiate a productivity paradigm in terms socio-economic transformation and progress. Whereas there are countries like Nigeria still at the transition stage, while there are counties that have innovation practices in their public services like Botswana, Namibia, South Africa etc. to name a very few that gives the assurance that though it is "Not yet Uhuru' in Africa, but there is a silver lining glittering there at the end of the tunnel (Olaopa, 2011:25).

This article sought to postulate the hypothesis that professionalization and innovation in the public service can go a long way in diffusing the brewing tension in the public sphere. The article has shown that the root cause of inefficiency and ineffectiveness, which manifests itself in poor service delivery to the citizenry, is the absence of professional public officials. This is the consequence of the appointment of staff that lacks the necessary skills and expertise and, concomitantly, the confidence required to address the needs and aspirations of the people (Ntliziywana, 2013:16). To guard against such practices, this article asserted that professionalism and innovation are the necessary adjunct to efficient public service. In this regard, various administrations in Nigeria have issued competency frameworks through reform to give practical effect to professionalization of public service.

\section{List of References}

- Abbott, A. 1988. The System of Professions: An Essay on the Division of Expert Labour. Chicago: University of Chicago Press.

- Adegoroye, G. 2005. Mainstreaming Ethics and Professionalism in the Public Service: The Nigerian Experience. A paper presented at the Conference in the African Charter and Related Reforms, Swakopmund, Namibia 3-7 October 
- Adegoroye, G. 2006. Public Service Reform for Sustainable Development: The Nigerian Experience. Keynote Address at the Commonwealth Advanced Seminar, Wellinton, New Zealand, February 20 - March 2.

- Adeyemo, D.O. \& Salami, A. 2008. A review of privatization and public enterprises reform in Nigeria. Contemporary Management Research, 4(4):401-418.

- Albury D. 2005. Fostering innovation in public services. Public Money and Management. 25: $51-56$

- Aucoin, P. 2002. Beyond the New in Public Management Reform in Canada: Catching the New Wave, in Christopher, D. (ed). The Handbook of Canadian Public Administration, Oxford: Oxford University Press, pp. 37-52.

- Balogun, M.J. 2008. Sustaining the Public Administration Reform Momentum in Africa: A Comparative Study of the Implementation, Monitoring, and Review of the Public Service Charter. A Consultant Report for the Federal Public Service Reform Programme.

- Barrett, D. 1998. Paradox Process: Creative Business Solutions Where You Least Expect To Find Them. New York: AMACOM

- Bland, T., Bruk, B., Kim, D. \& Lee, K. 2010. Enhancing Public Sector Innovation_Examining the Network-Innovation Relationship. The Innovation Journal: The Public Sector Innovation Journal. 15(3):1-17.

- Bloch, C. 2012. Measuring Public Innovation in the Nordic Countries: Copenhagen Manual. The Danish Centre for Studies in Research and Research Policy (CFA).

- Brunsson, N \& Kirsten, S.A. 2000. Constructing Organizations: The Example of Public Sector Reform. Organization Studies. 21:721-746.

- Damanpour, F. \& Gopalakrishnan, S. 1998. Theories of Organizational Structure and Innovation Adoption: The Role of Environmental Change. Journal of Engineering and Technology Management. 15(1):1-24.

- Dent, M; Chandler, J. \& Barry, J. 2004. Questioning the New Public Management. Aldershot: Ashgate Publishing.

- Eggers, B. \& Singh, S. 2009. The Public Innovators Playbook. Harvard Kennedy School of Government, Washington, DC.

- Evetts, J. 1999. Professionalisation and professionalism: issues for interprofessional care. Journal of Interprofessional Care. 13(2):119-128. 
- Fatile, J.O \& Adejuwon, K.D. 2010. Professionalisation and Civil Service Reforms in Nigeria: An Appraisal. In Terhemba, W \& Talla, N.S. (eds). Governance and Economic Development in the Fourth Republic. Lapai: Department of History and Archaeology, Ibrahim Badamasi Babangida University 179-180

- Fatile, J.O \& Adejuwon, K.D. 2010. Public Sector Reform in Africa: Issues, Lessons and Future Directions. Journal of Sustainable Development in Africa. 12(8):145-157

- Fitzsimons, C. 2010. Professionalising community development work and its implications for radical community education. Irish Journal of Adult and Community Education. 53(71):81-86

- Gold, J., Rodgers, H., \& Smith, V. 2002. The Future of The Professions: Are they up to it? Foresight 4(2):46-52.

- Gornitzka, Å. \& Larsen, I.M. 2004. Towards professionalization? Restructuring of administrative work force in universities. Higher Education. 47:455-471.

- Hamson, N. 2004. Why Innovation Doesn't Work: And what to do about it. The Innovation Journal: The Public Sector Innovation Journal. 9(1):1-7.

- Hargadon, A \& Sutton, R. 2000. Building an innovation factory. Harvard Business Review

- Hart, C.S. 2012. Professionalisation of Community Development in South Africa: Process, Issues and Achievements. Africanus. 42(2):55-61.

- Hood, C. 1991. A Public Management for all Seasons? Public Administration. 69 (1):3-19.

- Inyang, B.J \& Akaegbu, J.B. 2014. Redefining the Role of the Human Resource Professional (HRP) in the Nigerian Public Service for Enhanced Performance. International Journal of Business Administration. 5(1):90-99.

- Jane, J. 2008. What Does Professionalisation of Public Service Mean to Estonian Top Official? Estonia, Department of Public Administration, University of Tartu.

- Jessica, W, Christopher, S \& Kimberly, L. 2011. What Cannot Be Counted: Ethics, Innovation, and Evaluation in the Delivery of Public Services. The Innovation Journal: The Public Sector Innovation Journal. 16(2):1-17.

- Kamarck, E.C. 2003. Government Innovation around the World. Boston: Ash Institute for Democratic Governance and Innovation, John F. Kennedy School of Government, Harvard University.

- Koch, P. \& Hauknes, J. 2005. Innovation in the Public Sector. Oslo: NIFU STEP 
- Lankeu, M.R. \& Maket, J.L. 2012. Towards a Results-Oriented Public Service in Kenya: The Modern Human Resource Management Perspective. International Journal of Business and Social Science. 3(21):265-271.

- Larson, M.S. 1977. The Rise of Professionalism. California: University of California Press.

- Lawal, T \& Oluwatoyin, A. 2011. The Civil Service and Sustainable Development in Nigeria. Journal of Sustainable Development in Africa. 13(4):385-393.

- Le-Grand, J. \& W. Bartlett 1993. Quasi-markets and Social Policy. Basingstoke, UK: Palgrave Macmillan.

- Leung, T.T.F. 2011. The work sites as ground of contest: Professionalisation of work in China. British Journal of Social Work Advance Access 1:1-18.

- Lévesque, B. (2006). 'L'innovation dans le développement économique et dans le développement social', in Klein, J.-L. and D. Harrisson (eds), L'innovation sociale. Émergence et effet sur la transformation sociale, Québec : Presses de I'Université du Québec, pp. 43-70.

- Lévesque, B. 2012. Social Innovation and Governance in Public Management Systems: Limits of NPM and search for alternatives? Canada: Centre de recherche sur les innovations sociales (CRISES) Université du Québec à Montréal

- Maduabum, C. 2006. Reforming Government Bureaucracies in Nigeria: The Journey so far. Badagry: ASCON.

- Meintjes, C. \& Niemann-Struweg, I. 2009. The role of a professional body in professionalization: The South African Public Relations Case. PRism 6(2):

- Merx-Chermin, M. \& Nijhof, W.J. 2005. Factors influencing knowledge creation and innovation in an organisation. Journal of European Industrial Training. 29(2):135-147.

- Mishra, R.K. 1998. An Academic-Practitioner Divide: Public Administration Education in India.

- Mosher, F.C. 1982. Democracy and the Public Service. Oxford: Oxford University Press.

- Ntliziywana, P. 2013. The need for professionalization of local government in South Africa: the appropriate role of the upper spheres of government. University of the Western Cape, South Africa. 
- Nwanolue, B.O.G, \& Iwuoha, V.C. 2012. The Nigerian Civil Service and Promotion Of Sustainable Human Development: A Critical Analysis. Arabian Journal of Business and Management Review. 1(9): 12-21.

- OECD. 1995. Governance in transition: public management reforms in OECD countries. Paris: OECD.

- Okotoni, O. 2001. Problems and Prospects of Nigerian Bureaucracy. Journal of Social Sciences. 7(1): 223-229.

- Olaopa, T. 2009. Public Administration and Civil Service Reforms in Nigeria. Ibadan: University Press Plc.

- Olaopa, T. 2011. Strengthening Professionalism in the Public Service: An African Context and Perspective. A paper presented at the conference on "Promoting Professionalism in the Public Service: Strengthening the Role of Human Resource Managers in the Public Sector for the Implementation of the Africa Public Service Charter" 14 to 18 March 2011 in Addis Ababa, Ethiopia.

- Olaopa, T. 2014. The imperative of professionalising the Nigerian Civil Service. Being a keynote lecture delivered at the 4th International Conference of the Faculty of Administration, Nasarawa State University, on 'A century of Public Sector \& Corporate Governance in Nigeria, 1914-2014' held at the Assembly Hall, Keffi on the 8th of October, 2014.

- Pratt, C.B., \& Adamolekun, W. 2008. The People's Republic of China and FAPRA: Catalysts for theory building in Africa's public relations. Journal of Public Relations Research. 20(1): 20-48.

- Rasul, I \& Rogger, D. 2013. Management of Bureaucrats and Public Service Delivery: Evidence from the Nigerian Civil Service. Working Paper, June 2013, International Growth Centre, London School of Economics and Political Science.

- Rogers, E.M. 1983. Diffusion of Innovation. New York: The Free Press.

- Sørensen, E. \& Torfing, J. 2012. Introduction: Collaborative Innovation in the Public Sector. The Innovation Journal, The Public Sector Innovation Journal. 17(1):1-14

- Staffan, S. 2009. Professionalism in Public Service Management: The Making of Highly Qualified, Efficient and Effective Public Managers. Accessed online from www.oecd.org on February 18, 2015. 
- Tamekou, R. 2008. The National Governance Programme (2006-10) and the new the modernization of the administration: Cameroon and New Public Management International Review of Administrative Sciences. 74(2): 217-234.

- United Nations. 2006. Innovations in Governance and Public Administration. Replicating that Works, New York: United Nations.

- Van Bockel, J. 2005. Identities of public servants: performance-driven, but professional public managers. A paper presented at the EGPA Conference. Bern.

- Van de Walle, S. and G. Hammerschmid. 2011. Coordinating for Cohesion in the Public sector of the future. COCOPS Working Paper, 1, www.cocops.eu/publications/academicpublications, access 6 December 2011.

- Verhoest, K., Verschuere, B. \& Brouckaert, G. 2007. Pressure Legitimacy and Innovative Behaviour by Public Organizations. Governance: An International Journal Policy, Administration, and Institutions. 20(3): 469-497.

AUTHOR'S CONTACT:

AFEGBUA Salami Issa

Dept of Public Administration

Lagos State University, Ojo

Lagos, Nigeria

Email: issa99_afegbua@yahoo.com 